\title{
30 周年記念特別交流会
}

30 周年記念特別交流会は，学会創立 30 周年を記念した 事業の 1 つであり，第 29 回年次大会の初日の 6 月 20 日夕 方に開催された。その趣旨は，学会の会員などが集まり， 相互に交流しながら,この 10 年程度の技術進展をポスター 形式で情報交換し，これからの 10 年を一緒に語り合う場 を作ることであった。またリラックスした雲囲気にするた め，軽食やお酒も用意された。筆者は特別交流会の準備に 関わり，また当日の司会も担当した。そのため，以下の報 告には主観が混じるが，ご容赦頂きたい.

2 階の「太陽の間」(A 会場から D 会場までをつなげた 会場で，懇親会会場の 2 倍の広さ）に，101 件のポスター が掲示された. 30 周年記念事業実施委員会の横井委員長 (東京大学) の開会の挨拶と司会によるスポンサー企業の 紹介，そして荒川前会長（日本ゼオン(株)）の乾杯により， 特別交流会はスタートした（図 1，図 2).

特別交流会では，「交流」を促進する仕掛けが 2 つ用意 された. 1 つは， 1 分間スピーチである. 1 人 1 人の発表 者が自分のポスターの前で 1 分間のスピーチをし, その様 子が学生アルバイトによって $\mathrm{iPad} て ゙$ 撮影され, 会場前方 の 4 つのスクリーンにリアルタイムで投影された. 揭示し たポスターをもとにした技術進展のプレゼンテーションに 加え, 自社の CMソングを歌った方や, 地元のお酒（詳

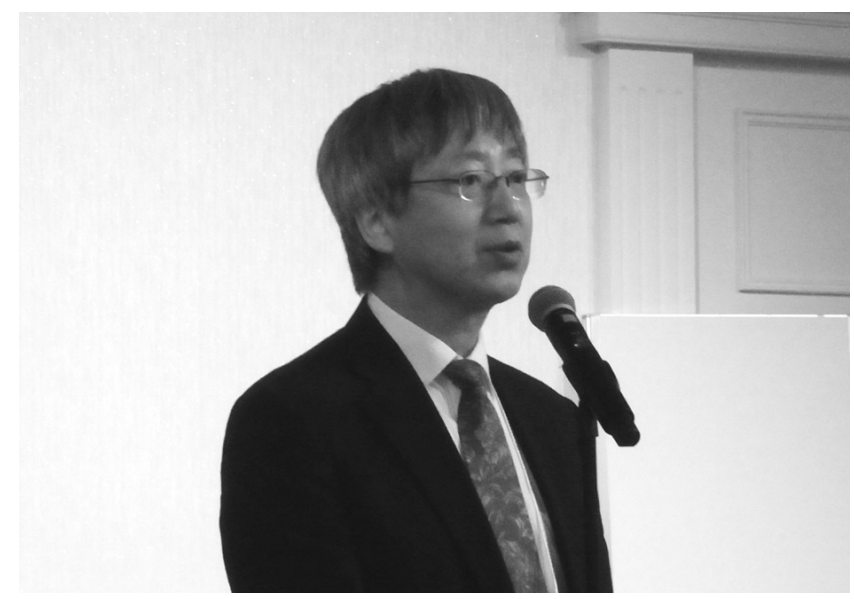

図 1 開会の挨拶（横井委員長）

JSPP 30th Anniversary Special Exchange Meetings

* Sato, Masahiro

パナソニック侏 ムズ社 メカトロニクス事業部 生産技術センター

三重県度会郡玉城町田宮寺（广519-0492）

sato.mshr@jp.panasonic.com

2018.7.18 受理

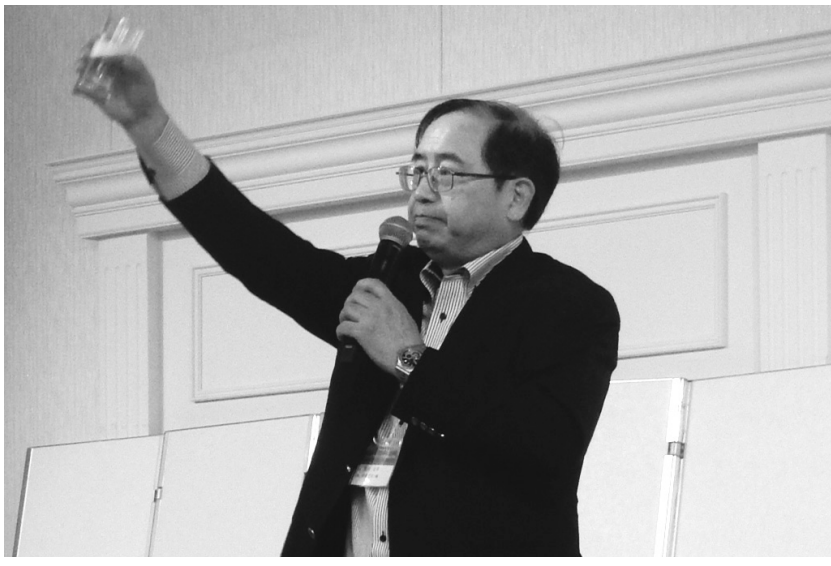

図 2 乾杯（荒川前会長）

細は後述）の良さを PR した方など，各自，趣向を凝らし たスピーチで，場を盛り上げていた。筆者は司会として， 右手にストップウォッチ，左手にベルを持ち，時間を大幅 に超過した場合は「チン!」と鳴らして発表を止める準備 をしていた。しかしほとんどの発表は時間内に終了し, 101 件のスピーチは予定よりも少し早めに終了した。

「交流」を促すもう 1 つの仕掛けは，全国の公設試の先 生方によって厳選された各地のお酒（日本酒 23 本，ワイ ン 2 本, 焼酎 1 本, 合計 26 本）であった. 特別交流会の 中盤でこれらのお酒がお披露目されると，多くの参加者が 会場後方のバーカウンターでお酒を楽しんだ（図 3 )。お 酒のお披露目が遅かったせいか，予想に反して，特別交流 会の終了時刻になってもお酒が残ってしまった。残ったお 酒は，翌日の懇親会に持ち越された。

以上 2 つ仕掛けにより，ポスターやサンプルを見なが ら議論をしたり旧交を温める姿が，会場のあちこちで散見 された（図 4).

最後に，齊藤前副会長（東京工業大学）による閉会の挨 拶があり，特別交流会は終了した（図 5)。名残惜しそうな 参加者も多かったが, 翌朝の講演に備えて会場レイアウト を元に戻す必要があり, 急いでポスターが外されていった。 特別交流会で掲示されたポスターの予稿が，「創立 30 周 年記念冊子」に揭載されている. ポスター同様, ここ 10 年程度の学術研究・技術開発の進展が研究機関や企業ごと にコンパクトにまとめられており，「研究総覧」のような 貴重な資料になっている. ただ, 通常の研究総覧と異なり, ・10 年というロングスパンの動向がまとめられている.

・日本国内限定ではあるが，101件という多数の研究機関 や企業における動向が集められている. 

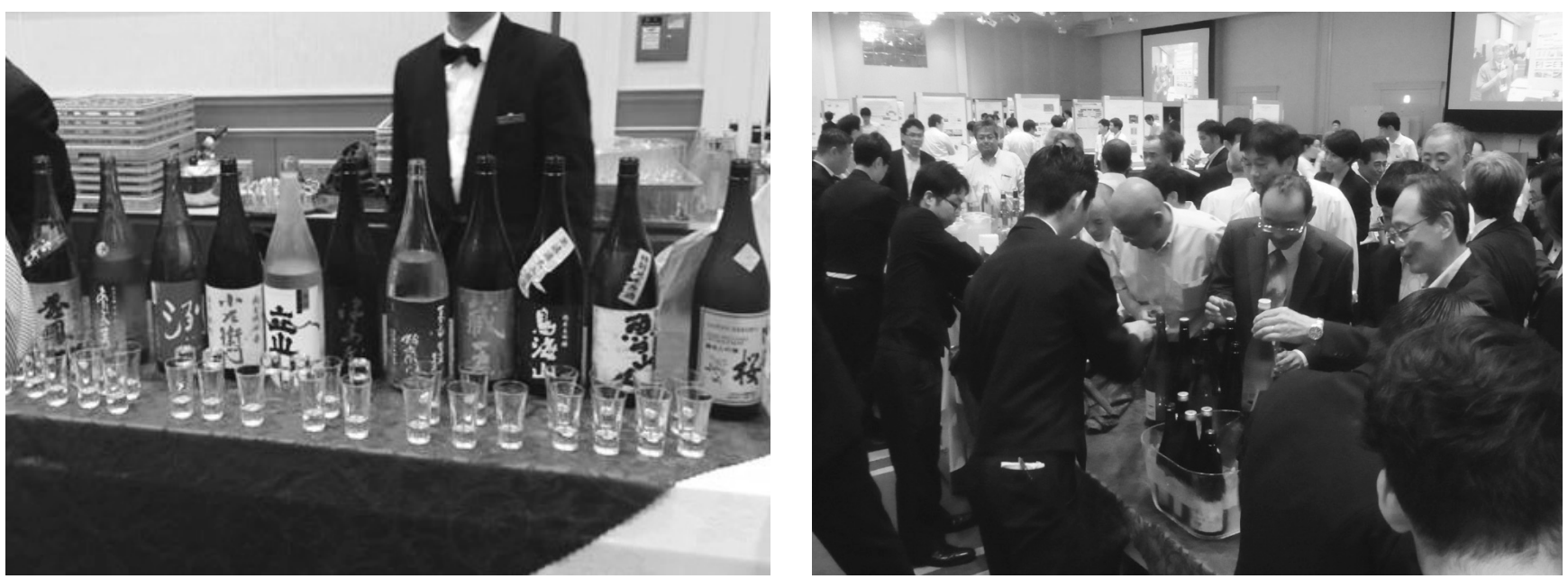

図 3 各地のお酒を楽しむ皆様
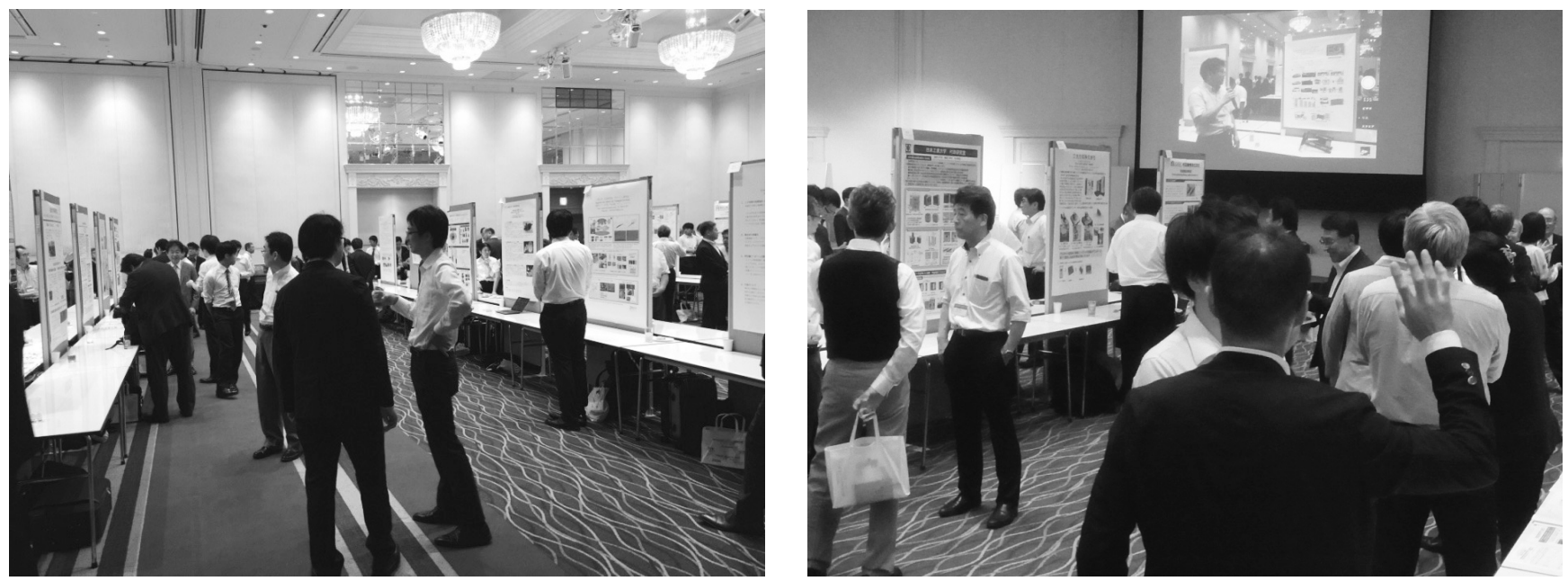

図 4 会場風景

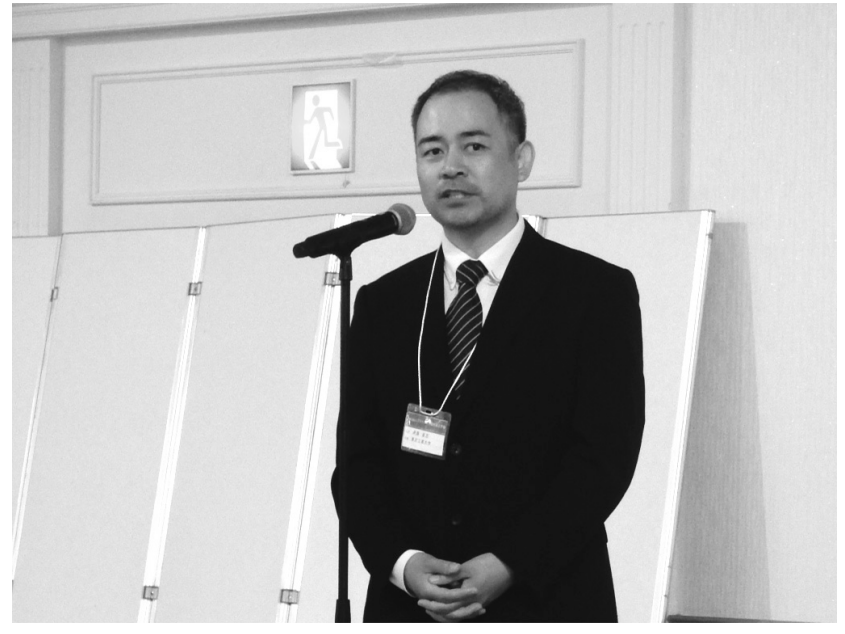

図 5 閉会の挨拶（齊藤前副会長）
という特徴があり, 創立 30 周年記念にふさわしい「成形 加工に関する知のストック」を作ることができたのではな いかと思う．記念冊子をお持ちの方は，「記念」としてし まい込む前に是非とも一度目を通して, 会誌「成形加工」 2018 年 7 月号「学会創立 30 周年記念号」と併せて日頃の 学術研究や技術開発に役立ててほしい。

特別交流会のようなイベントは，本学会としては初の試 みであった，そのため準備段階や当日の運営において，良 くも悪しくも「走りながら考える」部分があり，関係した 方々にご迷惑をかけた部分が少なからずあったと感じる. しかし，特別交流会を何とか無事に終了できたのは，ポス 夕ー発表の呼び掛けにご協力いただいた皆様, 会の主旨に 賛同して発表・参加していただいた皆様，運営にご尽力い ただいた 30 周年記念事業実施委員会の委員や学生アルバ イトの皆様など，多くの方々のご協力の賜物である。ここ に記して，感謝申し上げる。 